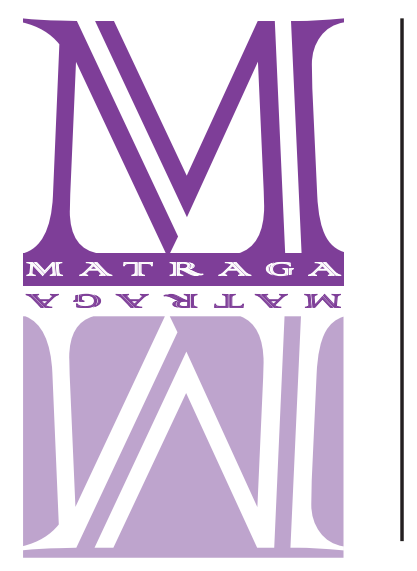

\title{
Maria dos Canos Serrados (2013), de Ricardo Adolfo, e a recriação pulp do real
}

\author{
Natália Ubirajara Silva \\ Secretaria Municipal de Educação de Porto Alegre, Brasil \\ https://orcid.org/0000-0002-6575-1249
}

\begin{abstract}
RESUMO
O presente artigo analisa o romance Maria dos Canos Serrados (2013), de Ricardo Adolfo, buscando compreender de que forma o realismo se apresenta na ficção portuguesa do século XXI. Percebe-se um deslocamento do termo "realismo" no escopo da literatura portuguesa, entendido como retrato da realidade (no século XIX), questionamento engajado da realidade (com o neorrealismo, no século XX) e recurso em favor da narratividade do romance (século XXI). Caracterizada pelo ritmo dinâmico próprio da narrativa cinematográfica e valendo-se do espaço, da denominação (Cassirer) e de inverossimilhanças narrativas (Santo Agostinho e Todorov), a obra de Ricardo Adolfo apresenta as atuais mazelas da sociedade, num realismo social e numa estética pulp que se afastam das principais vertentes do romance português contemporâneo.
\end{abstract}

PALAVRAS-CHAVE: Literatura portuguesa; Realismo; Romance; Ricardo Adolfo.

\section{Maria dos Canos Serrados (2013), by Ricardo Adolfo, and the pulp recreation of reality}

\section{ABSTRACT}

This article analyses the novel Maria dos Canos Serrados (2013), by Ricardo Adolfo, aiming to understand the ways realism presents itself in $21^{\text {st }}$ century's Portuguese fiction. One perceives a change of meaning of the term realism in the scope of Portuguese literature, understood as a portrait of reality (in the $19^{\text {th }}$ century), as an activist questioning of reality (with neorealism, in the $20^{\text {th }}$ century) and as a resource in favor of the novel's narrativity ( $21^{\text {st }}$ century). Characterized by the dynamic rhythm that befits a cinematographic narrative and making use of space, denomination (according to Cassirer) and narrative implausibility (according to Santo Agostinho and Todorov), Ricardo Adolfo's work presents the current diseases of society, in a social realism and pulp aesthetics that stand apart from the main strands of contemporary Portuguese novel.

KEYWORDS: Portuguese literature; Realism; Novel; Ricardo Adolfo. 


\section{Considerações iniciais}

O presente artigo tem como objetivo analisar o realismo no romance Maria dos Canos Serrados (2018b), de Ricardo Adolfo. Nascido em Luanda em 1974, o escritor viveu em Lisboa e radicou-se em Tóquio. Sua obra circula por diversos gêneros, como a crônica, o romance e a literatura infantil. O romance Maria dos Canos Serrados, lançado em Portugal em 2013, é a única obra do autor publicada no Brasil até o momento. Antes de nos debruçarmos sobre ela, faremos um breve percurso pelo termo "realismo" no romance português, estabelecendo três momentos distintos.

O primeiro momento do realismo refere-se ao estilo de época que surge como resposta e ultrapassagem ao movimento romântico. Autores como Stendhal e Honoré de Balzac, conforme Auerbach, "quebraram a regra clássica da diferenciação dos níveis, segundo a qual a realidade quotidiana e prática só poderia ter seu lugar na literatura [...] de forma grotescamente cômica ou como entretenimento agradável, leve, colorido e elegante" (2013, p. 500). Aguiar e Silva reconhece nos autores realistas do século XIX o empenho em "figurar a totalidade da vida" (1979, p. 239) com a exatidão de uma fotografia ou de um estudo científico, destacando "as personagens e os acontecimentos triviais e anódinos extraídos da baça e chata rotina da vida" (1979, p. 260). O prosador realista, portanto, seria um escritor interessado "primacialmente pelos outros" (1979, p. 235).

O realismo lusitano do século XIX tem como maior expoente Eça de Queirós que, ao problematizar o catolicismo, a monarquia e a moral pequeno-burguesa, volta o olhar para os vícios da sociedade, retratando-a sem máscaras. Aparecem aí padres imorais, irmãos incestuosos, adúlteros, personagens que traduzem a decadência portuguesa.

O termo "realismo" reaparece anos depois, batizando a corrente literária denominada neorrealismo, que compreende obras nas quais predomina a temática de cunho social - seja regionalista, seja questionadora da ditadura de Oliveira Salazar. Destacam-se, nesse período, Gaibéus (1939) de Alves Redol, e Uma abelha na chuva (1953), de Carlos de Oliveira. Numa reação a esse realismo engajado, a ficção portuguesa promove, entre as décadas de 1950 e 1970, "uma violentíssima contestação da conceção realista de romance, operando-se tanto a desconstrução das suas categorias clássicas quanto a sua substituição por um esteticismo autoral" (REAL, 2012, n.p.), no qual predominam a memória e a imaginação em detrimento do real exterior. Como exemplo desse afastamento do real e da prevalência do experimentalismo, temos os romances $O$ Delfim (1969), de José Cardoso Pires, e Bolor (1968), de Augusto Abelaira.

Após a Revolução dos Cravos, em 1974, e a perda dos territórios ultramarinos, mantém-se a experimentação formal e acentua-se o predomínio da temática identitária, presente em romances como A jangada de pedra (1986), de José Saramago, e As naus (1988), de António Lobo Antunes. Nos romances desse período, o questionamento dos rumos da nação lusitana se dá, muitas vezes, pelo viés do fantástico e do alegórico.

A partir de meados da década de 1980, configura-se uma nova forma de escrita, que se afasta do esteticismo e do fantástico, promovendo a assunção da literatura "ao modo de Eça, como descrição realista da realidade" (REAL, 2012); este é o terceiro momento do realismo em 
Portugal. No século XXI, como consequência desse resgate, a narrativa portuguesa passa a dar "importância à narratividade, à fluência sintática, à imaginação semântica, à simples capacidade de contar (de um modo original) uma história singular, [...] escrita que não pretende nem ser eloquente nem arrogar-se de originalidade" (REAL, 2012, n.p.). Resgatando a terminologia de Tomachevski (1971, p. 173), pode-se dizer que os escritores contemporâneos voltam a dar valor à fábula, "sem se cair na incompreensibilidade" (REAL, 2012) e nas tramas intrincadas, predominante nas décadas de 1950 e 1960.

\section{0 realismo pulp de Ricardo Adolfo}

Qual é o lugar da prosa de Ricardo Adolfo na ficção portuguesa contemporânea? Em seu estudo dos principais romancistas portugueses de 1950 a 2010, Real define a obra de Adolfo pela linguagem, citando como características o léxico suburbano e a narratividade. Contudo, o traço mais marcante de sua produção é o cariz "socialmente realista" (2012, n.p.), o qual se afasta das principais vertentes do romance lusitano do século XXI, como o fantástico-alegórico de José Saramago, o literário-filosófico de Gonçalo M. Tavares, a narrativa poética de José Luís Peixoto e Valter Hugo Mãe, a teia de intertextos de Afonso Cruz e a fragmentação lúdico-estética do Lobo Antunes mais recente.

Em Maria dos Canos Serrados, Ricardo Adolfo compõe um mosaico de tipos, apresentando toda sorte de indivíduos à margem da sociedade e/ou da lei: a mulher pobre e funcionária subalterna que cai na criminalidade, a diretora que leva a empresa à falência, o líder sindical, o desempregado, o gigolô, o ex-detento, a mãe solteira, o vendedor de joias falsificadas, o emigrado retornado. Vale registrar que Lobo Antunes, em Meu Nome é Legião (2007), já havia tematizado a violência urbana e outros problemas sociais, porém a construção dos romances é completamente distinta. O ritmo da narrativa de Adolfo é frenético, ao passo que a narrativa de Lobo Antunes exige do leitor uma leitura ruminada (NIETZSCHE, 2009, p. 14), lenta, ponderada.

Pode-se traçar, ainda que com restrições, um paralelo entre a produção de Ricardo Adolfo e a obra do brasileiro Rubem Fonseca, que retira da marginalidade personagens que habitavam as páginas policiais - ladrões, detentos, prostitutas, policiais, delegados. $\mathrm{O}$ realismo de Fonseca - o "brutalismo" (BOSI, 1978, p. 18) ou o "realismo feroz" (CANDIDO, 2006, p. 255) - caracteriza-se pela crueza na linguagem, e é a partir dessa marca que se podem ouvir ecos da Lúcia McCartney fonsequiana na voz de Maria dos Canos Serrados.

No entanto, embora seja válido aproximar o realismo nas obras de Fonseca e Adolfo, o retrato da marginalidade construído pelo romancista português em Maria dos Canos Serrados difere do fonsequiano por recobrir-se de uma roupagem "pulp/noir" (ADOLFO, 2018a, on-line). Isso significa que a obra de Adolfo apresenta ao leitor um realismo distorcido e caricato, que se sabe simulacro, desembocando no absurdo - tal como as pulp magazines e pulp fictions das primeiras décadas do século XX, recheadas de sexo, violência e humor negro. Em Maria dos Canos Serrados, a precipitação dos eventos leva a um clímax e um desfecho à la Quentin Tarantino (em Pulp Fiction, 1994) ou Bong Joon-ho (em Parasita, 2019) - e a relação do romance com a narrativa 
fílmica não é fortuita, uma vez que Ricardo Adolfo também é roteirista. Como outros autores contemporâneos, Adolfo se vale do cinema "como alusão, como referência, e como inspirador de técnicas: ritmo narrativo, cortes, flashbacks" (PERRONE-MOISÉS, 2017, p. 260).

Para Aguiar e Silva, "através dos tempos, a literatura tem sido o mais fecundo instrumento de análise e de compreensão do homem e das suas relações com o mundo" (1979, p. 110). No entanto, essa análise do real não é objetiva ou neutra, passando por um ponto de vista e por uma construção da linguagem; a lente que olha para o mundo e o ficcionaliza não o reproduz fielmente. Conforme explica Perrone-Moisés, "por dar uma forma e uma significação ao que é narrado, o romance tem uma função crítica” (2017, p. 111). Assim, o olhar lançado pelo romancista sobre as realidades que o cercam se traduz em linguagem, estruturas e elementos narrativos não arbitrários; em Maria dos Canos Serrados, a opção por retratar uma parcela da sociedade portuguesa de forma realista e por intermédio de uma estética pulp é carregada de significação.

\section{Os espaços do romance: a casa, a empresa, o bar}

Maria dos Canos Serrados, numa narrativa em primeira pessoa, estruturada em pequenos capítulos epistolares, apresenta a transformação de uma secretária de empresa telefônica em líder de gangue - Maria dos Canos Serrados y Sus Muchachas (ADOLFO, 2018b, p. 212). Sintonizado com a cultura pop e incorporando a agilidade da narrativa fílmica, o romance mescla sexo, humor, drogas e violência. Por trás de situações e diálogos muitas vezes cômicos e grotescos, descortinam-se temas como exploração, desemprego, violência, corrupção, preconceito, abuso sexual, dependência química, exposição nas redes sociais, miséria, emigração e imigração.

Maria é uma mulher de 29 anos passando por crises em diversos níveis, as quais ensejam o surgimento da líder de gangue Maria dos Canos Serrados. Podemos compreender os gatilhos dessas crises a partir do espaço narrativo: a casa, a empresa telefônica e o Bar e Salão de Fogo Nandos.

A casa de Maria é o espaço da intimidade, marcado pelas experiências sexuais (com o Velho/ Velhinho e com parceiros ocasionais, como Tarzan e Tarzan II). A casa também é espaço da ausência - a eterna espera de Maria pelo Velhinho, que raramente a visita - e da indiferença. Já no primeiro capítulo descortina-se a falta de reciprocidade entre Maria e o Velho:

Nós às vezes também fumamos os restos do chocolate ou damos o último tirinho. Mas sentimo-nos mal. Sabemos que não o devíamos fazer. Tu não. Tu nem pensas nisso. Quando vês uma carreirinha de sobra, se for preciso até vais para a cozinha só para não a teres de dividir, como aconteceu no mês passado (ADOLFO, 2018b, p. 8).

A atitude no uso de entorpecentes espelha todo o relacionamento. Ao longo da narrativa, Maria é sistematicamente negligenciada pelo Velhinho: "Para nos foderes por completo decidiste que não podias deixar de trabalhar durante uma noite para vires festejar o nosso aniversário" (ADOLFO, 2018b, p. 11). O fato de ambos se conhecerem desde a infância pode justificar a dificuldade em romper o vínculo: "não é fácil, não se deixa ir alguém que se conhece desde sempre" (2018b, p. 44). 
Nas entrelinhas das queixas e declarações de amor dirigidas ao amante, percebe-se que também o Velho tem uma história de vida difícil: negro, pobre, ganha a vida como gigolô; sua clientela consiste em turistas idosas, "estafermas com três queixos" (2018b, p. 129). Maria trata o Velho com superioridade por ter maior nível cultural e por ser branca: "Hoje recebemos uma mensagem tua que dizia - eu te vou deixar. Sabemos que tua cabeça de preto às vezes pensa mesmo à preto e que te esqueceste de escrever nunca. [...] És mesmo preto" (2018b, p. 43). Geralmente, o discurso de superioridade é uma tentativa de revide pelo desprezo com que é tratada pelo Velhinho. Mesmo quando os dois amantes passam a coabitar, a indiferença se mantém: o Velho não consegue manter relações sexuais com Maria à noite pois, secretamente, leva clientes para casa durante o dia. Essa traição - espécie de conspurcação do espaço da casa -, somada à demissão de Maria, é um turning point na progressão narrativa.

É com ironia que Maria nos introduz em seu espaço de trabalho, mostrando ao leitor "Mais uma empresa nacional que não vai conquistar a Europa, a Ásia e o ciberespaço porque os pobres que aqui trabalham não são capazes de acompanhar a genialidade de quem quer liderar a empresa" (2018b, p. 48). A situação da companhia telefônica é um retrato da economia portuguesa pós-crise mundial de 2008, cujo advento surpreendeu um Portugal já estagnado e afundado em dívidas. Consequentemente, houve um aumento histórico na taxa de desemprego (VAREJÃO, on-line).

Maria foi uma das funcionárias surpreendidas pela crise econômica nacional e pela má administração da empresa. Tendo abandonado a faculdade, sua grande esperança de ascensão era tornar-se diretora. Para isso, construiu uma trajetória como braço direito de sua chefe - a doutora -, suportando assédios de todos os tipos e tomando atitudes questionáveis para garantir seu futuro: "Mentíamos por ela porque queríamos acreditar na mentira de que nos ia fazer directoras" (ADOLFO, 2018b, p. 19). As promessas da doutora mostraram-se falsas quando os negócios escusos e os esquemas na gestão da companhia vieram à tona.

O sonho de chegar à diretoria se traduz em salários atrasados e demissão. Quem detinha cargos na empresa teve os salários quitados; "a gente pequena, nós incluídas" (2018b, p. 35) não recebeu nada. $\mathrm{O}$ escândalo financeiro leva até mesmo emissoras de televisão à empresa - as quais, "a enfiar a nossa miséria nos telejornais todos" (2018b, p. 97), promovem um espetáculo à custa do sofrimento alheio.

A fim de reivindicar os direitos dos trabalhadores - único motivo para "aquela palhaçada de Abril" (2018b, p. 63), um membro do sindicato se alça à liderança dos funcionários, negando-se a reconhecer a demissão coletiva e, por fim, tornando-se ele mesmo o novo diretor da firma reproduzindo o ciclo em que o oprimido se torna o opressor: "O grande líder é a nova doutora" (2018b, p. 140). Para Maria, bem como para todos os portugueses da classe trabalhadora, é frustrante ver que os discursos revolucionários do líder sindical são ilusórios: "Por momentos, ainda acreditámos que desta vez ia ser diferente, que tínhamos direitos, que iria ser feita justiça, que por lá sermos pobres não íamos ser molestados mais uma vez" (2018b, p. 140). O novo patrão propõe que os funcionários demitidos se tornem acionistas da empresa; Maria, sem dinheiro, sente-se roubada e humilhada (2018b, p. 209).

Atravessando cada vez mais dificuldades financeiras e vendo que a intervenção do líder sindical na firma foi infrutífera e gerou ainda mais injustiças, Maria desabafa com o Velhinho: 
"Quinze caixas daqueles minutos [cartões telefônicos] são nossas, sempre foram, e com juros ainda são mais. E agora, por sermos tão pobres como os outros pobres, não lhes podemos tocar (2018b, p. 139). O Velho, por sua vez, propõe o roubo dos "cartões pré-pagos com milhões de minutos" (2018b, p. 9), guardados na empresa:

\section{QUERIDO VELHINHO,}

Obrigada por compreenderes a injustiça da situação. E obrigada, mais ainda, pela ideia criminosa. Estás quase perdoado. É verdade que, se nos querem roubar, temos todo o direito de os roubar primeiro. É uma forma de defesa pessoal. Anulamos o crime cometendo-o primeiro. Só os teus neurónios de preto é que poderiam chegar a uma conclusão dessas (2018b, p. 142).

Maria acata a lógica de roubar a empresa como reparação de uma injustiça, pondo em curso a "Operação Tempo Roubado" (2018b, p. 145). O Velho e seu irmão, Jesus, a ajudariam na empreitada; contudo, após tomar conhecimento das contínuas traições do Velhinho, Maria decide roubar a telefônica sozinha: "Temos de nos fazer à vida. Mas vamos ter de ser nós a puxar este rebanho" (2018b, p. 181).

O Bar e Salão de Fogo Nandos é um "clube [de tiros] privado para criminosos e simpatizantes" (2018b, p. 24), situado no terceiro andar de um prédio residencial - o que acarreta boa dose de intrigas cômicas com a vizinhança. Introduzida nesse espaço por um amigo ex-detento, Maria se familiariza aos poucos com o ambiente e seus frequentadores e aprende a atirar - "Estamos a emancipar-nos no mundo dos delinquentes" (2018b, p. 51).

É a partir das idas esporádicas ao Nandos que a trajetória da narradora começa, paulatinamente, a se reinventar. Curiosamente, o ambiente avesso à presença feminina se torna um espaço de emancipação: "Abrir fogo não é melhor do que sexo, como nada o pode ser, mas deixou-nos muito aliviadas. Acabámos a noite em casa, sozinhas e felizes" (2018b, p. 25). No Bar do Nandos, Maria cresce como mulher: seduz e manipula os donos do lugar (Nandos, um velho impotente, e Geleia, um retornado de África que mal consegue segurar uma arma) e mostra que, na verdade, o homem é o "sexo fraquinho" (2018b, p. 206). Essa impressão é corroborada após Maria aprender a atirar com uma espingarda Baikal de canos serrados: "começámos a largar lume à mulher com Mê grande" (2018b, p. 176). A frequência ao Nandos viabiliza para Maria o plano desesperado de reparar as injustiças sofridas em seu trabalho. Ao ver a vida amorosa e as ambições profissionais ruírem, Maria encontra na arma uma saída, um meio de solucionar seus problemas imediatos.

\section{A recriação do real em Maria Dos Canos Serrados}

Perrone-Moisés e Real reconhecem nos prosadores contemporâneos a reinserção do real no mundo romanesco, e um dos recursos mais utilizados é o detalhismo, "a descrição minuciosa de realidades parciais e aparentemente insignificantes [...], uma forma de preservar o que a vida tem de mais precário e perecível num mundo em acelerada transformação" (PERRONE-MOISÉS, 2017, p. 109). A atenção ao detalhe e a descrição de elementos aparentemente corriqueiros 
ou insignificantes é um "simulacro persuasivo" (RICCEUR, 2012, p. 21) que visa a criar um efeito de real (BARTHES, 2004), autenticando os relatos e "fornecendo-lhes uma concretude referencial que o signo verbal não tem, por ser apenas uma representação do real" (PERRONE-MOISÉS, 2017, p. 213). Desse modo, representam-se "ações banais [...] que, justamente por serem muito comuns, contribuem para que o leitor se sinta dentro do livro como dentro da realidade" (PERRONE-MOISÉS, 2017, p. 213).

No romance de Adolfo, a menção a problemas do dia a dia ajuda a construir esse efeito de real: "A conta do cartão de crédito está para cair. Cairá no vazio da nossa conta Plus Debts Fuck" (ADOLFO, 2018b, p. 124); “já tens espaço para as tuas coisas de higiene na cozinha. Não esqueças de trazer a mala. Vai ficar em cima da nossa enquanto não comprarmos uma cómoda" (2018b, p. 57-58). Da mesma forma, as referências à cultura pop situam o leitor no campo da realidade: a epígrafe (trecho da canção In for the kill, do duo britânico La Roux) e a menção a Bad Romance, de Lady Gaga são alusões intertextuais que apontam para similaridades de sentimentos e anseios entre os sujeitos líricos das canções e a personagem romanesca.

No universo de Maria dos Canos Serrados, o efeito de real se dá, sobretudo, pela apresentação da vida sem filtros: "se não estás à nossa porta amanhã de manhã, antes do meio-dia, assim que te pusermos as unhas em cima arrancamos-te os colhões pela língua e enforcamos-te no poste da luz com o intestino grosso" (ADOLFO, 2018b, p. 59); "Oferecemos-lhe várias hipóteses para começar. Surpresa das surpresas: ficou indeciso entre o cu e a boca. Mais surpresa ainda: decidiu-se pelo cu, voilà. Pusemo-nos a jeito, de caras para um azulejo [...]” (2018b, p. 188). É a essa forma peculiar de recriação adolfiana do real no mundo do romance - o detalhismo, a linguagem sem filtros, a violência, o submundo da criminalidade, a cultura pop, o humor negro - que temos denominado realismo pulp.

Uma particularidade em Maria dos Canos Serrados é a mimese da linguagem oral. Embora Maria seja a narradora, opera-se uma cisão: o discurso do narrador - a enunciação, segundo Ricœur - segue as convenções da escrita; no diálogo, o discurso da personagem - o enunciado, no entendimento de Ricœur (2012, p. 152) - cria-se uma representação singular da oralidade:

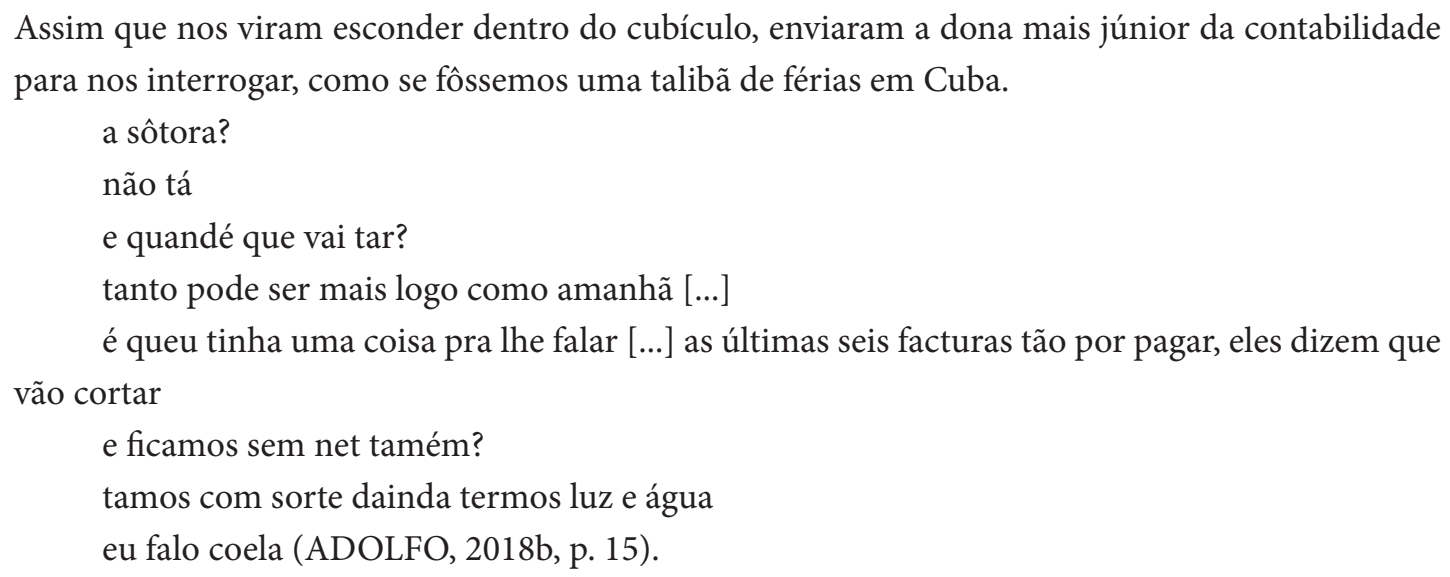

Essa marca de estilo do autor é mais um recurso na arquitetura de uma obra realista, uma vez que, segundo Perrone-Moisés, “é sabido que a linguagem verbal não pode representar exa- 
tamente o real, ela só pode referir-se a ele. Ora, reproduzir uma fala é a forma mais perfeita de realismo, já que a linguagem de uma personagem pode ser a mimese exata de um acontecimento discursivo" (2017, p. 234).

Outra forma de criar um "simulacro persuasivo" da vida (RICCEUR, 2012, p. 21) é a estruturação da narrativa em gênero epistolar, capaz de "transferir pela escrita, sem perda de potência persuasiva, a força de representação ligada à palavra viva ou à ação cênica” (2012, p. 20). Os capítulos do romance são mensagens (e-mails? Mensagens de texto? Desabafos imaginários?) que Maria dirige ao Velho. A ausência de resposta transforma o romance num grande monólogo, e o silêncio do interlocutor é uma manifestação formal da indiferença do amante para com a narradora.

Em sua narrativa realista, Adolfo lança mão de recursos que explicitam ao leitor a obra enquanto recriação do real - quebrando, paradoxalmente, o efeito de realidade. Destacam-se, dentre esses recursos, a denominação e as inverossimilhanças.

Uma característica singular em Maria dos Canos Serrados é a denominação das personagens: algumas são apresentadas pela narradora pelo nome (Maria, Jesus, Augusta, Luísa, Jorge) ou apelido (Tina, Nandos, Geleia); outras são referenciadas de acordo com sua condição ou ocupação (o Velho/Velhinho, a doutora, o homem do sindicato/grande líder, o ex-cadastrado). Constata-se que, via de regra, as personagens não nomeadas têm algum tipo de ascendência sobre Maria, determinando suas ações: a doutora é responsável pela sua demissão; o líder sindical, que assume o controle da empresa, exige de Maria participação como acionista como condição para ser recontratada; o amigo ex-presidiário introduz Maria no espaço do Bar e Salão de Fogo Nandos, local onde ela tem o primeiro contato com armas de fogo e com a Baikal de canos serrados; o Velho, amante gigolô, é quem sugere a Maria o plano de roubar os cartões telefônicos da empresa como retaliação. As ações dessas quatro personagens inominadas influenciam diretamente as decisões de Maria e precipitam os eventos narrativos até o seu desfecho.

Ainda quanto à denominação em Maria dos Canos Serrados, ressaltam-se as ressonâncias bíblicas; na realidade pulp decadente, os nomes bíblicos se despem de sua sacralidade. A fim de compreender essa alusão intertextual, pode-se resgatar a hermenêutica de matriz agostiniana, segundo a qual os nomes próprios são segmentos interpretáveis (TODOROV, 1980, p. 93) e, pela sua análise, o leitor pode solucionar diversos enigmas (AGOSTINHO, 2002, II, XVI, 23). Na mesma linha, Cassirer destaca a correspondência entre o nome e a essência: "o nome não só designa, mas também é esse mesmo ser" (1972, p. 17).

Portanto, os nomes de Maria e Jesus, resgatados por Adolfo, são relevantes na conformação das personagens do romance. Maria remete não apenas à mãe de Cristo, virgem e pura, mas também à Madalena e à irmã de Marta e Lázaro, ambas prostitutas convertidas. A Maria dos Canos Serrados ressignifica esse nome: ela não é santa - "nós preferimos a fogueira ao altar" (ADOLFO, 2018b, p. 21) - e tem trajetória inversa às das personagens bíblicas, uma vez que, para ela, não há redenção possível. Jesus, por sua vez, referido jocosamente pela narradora como "filho do Senhor" (2018b, p. 214), é um gigolô, meio-irmão do Velhinho. Mesmo não sendo puro ou perfeito, o Jesus romanesco apresenta traços comuns ao homônimo escriturístico, mostrando-se bondoso para com Maria, por quem nutre um amor platônico. Em troca, é tratado 
com indiferença, uma vez que Maria o considera muito bondoso para que haja relação entre os dois: "devemos amar quem pior nos trata. [...] A falta de amor-próprio também se herda" (2018b, p. 202).

É por meio de Jesus que Maria conhece a verdade e rompe com o Velho: "A raiva que regamos todos os dias por ti voltou a florescer, graças às palavras que o Jesus decidiu partilhar conosco. Mais humilhante do que teres feito uma cliente na nossa cama é teres feito várias" (2018b, p. 190). Ao fim do romance, como consequência por sua participação em um tiroteio no Nandos, Jesus tem a perna amputada. Inversamente ao Jesus bíblico, que vence o mal por meio dos açoites e da crucificação, o Jesus de Adolfo é arruinado por suas feridas: "Jesus, agora perneta e sem saber se a SS [Segurança Social] lhe vai patrocinar a prótese, [...]. Coitadinho, não o espera uma vidinha fácil. Um coto no lugar da perna não deve ser a fantasia mais requisitada no vosso negócio" (2018b, p. 214). Altruísta e benigno, Jesus não tem lugar nesse mundo.

Na recriação pulp do real operada por Adolfo, alguns elementos sobressaem pela incongruência com a pretensão de realidade. Quanto a esse aspecto, vale recordar novamente a hermenêutica agostiniana, resgatada por Todorov, segundo a qual toda passagem que difere do restante do texto por inverossimilhanças doutrinais e materiais (1980, p. 91-92) ou pela superfluidade indica a necessidade de interpretação. Transpondo esse princípio hermenêutico para o contexto do romance realista contemporâneo, elementos que escapem ao efeito de real requerem um olhar mais atento da parte do leitor.

Um desses aspectos seria a narração na primeira pessoa do plural. O estranhamento ocorre já no primeiro capítulo do romance: "VELHINHO, Estamos fodidas. Estamos muito fodidas. [...] Vamos abrir outra garrafa e cheirar o que ainda houver, para clarear as ideias" (ADOLFO, 2018b, p. 7). O uso do plural remete à cosmogonia do Livro do Gênesis, em que Deus cria o mundo por meio da palavra usando a primeira pessoa do plural: "Deus disse: 'Façamos o homem à nossa imagem, como nossa semelhança"” (Gn 1,26). Como o criador bíblico, Maria também se reconhece em sua criatura:

\footnotetext{
[Nandos] Tirou a chave do colar de ouro, ajoelhou-se, e do fundo do cofre tirou uma Baikal de canos serrados. [...] De um ponto de vista profissional, não é suposto matar ninguém, mas consegue deixar vários agarrados às entranhas ao mesmo tempo. Dispersa em vez de ir a fundo. Tão parecida connosco que até faz impressão. [...] Esta cabra só pode ter sido criada à nossa imagem e semelhança. Está sempre a criar danos colaterais e não se importa de não acertar em cheio, desde que leve muitos consigo. Mais uma fã dos múltiplos (ADOLFO, 2018b, p. 172-173).
}

O ápice da cosmogonia cristã é a formação do homem, feito à imagem de Deus; igualmente, o primeiro contato com a Baikal de canos serrados instaura uma nova Maria, que vê na Baikal "uma filha" (2018b, p. 176) à sua imagem e semelhança. Tal como o Deus cristão, uno e trino multíplice -, Maria traz muitas dentro de si (a amante, a amiga, a funcionária, a libertina), e esse traço de sua personalidade se expressa na Baikal, arma de estilhaços múltiplos, que se dispersam e atingem diversos alvos de uma vez só. Da mesma forma, no decorrer da narrativa, o leitor perceberá que aqueles que cruzam o caminho de Maria (o grande líder sindical, o Velho, Jesus, Nandos, etc.) sofrem os danos colaterais desse contato. 
A espingarda Baikal de canos serrados assume características humanas, como se tivesse consciência e vontade - "A Baikal [...] decidiu abrir as duas goelas ao mesmo tempo e oferecer-lhe todo o chumbo que trazia no bucho" (2018b, p. 209). A arma passa a ter nome próprio - a "Serradinha" (2018b, p. 211) - e termina por fundir-se à Maria, proporcionando a assunção de uma nova identidade: "Maria dos Canos Serrados" (2018b, p. 218). Maria se une de forma estreita à arma por reconhecer similaridades entre ambas. Ela acredita que a Baikal "não estava a pedir grandes direcções da vida, queria apenas que fôssemos capazes de a domar quieta, antes, durante e depois. Faz parte do clube das que gostam de ser agarradas à força" (2018b, p. 176). Nessa etapa de sua jornada, Maria ainda é dependente e passiva; sente-se desafiada a controlar essa arma tão destrutiva, "mula velha com coice impróprio para meninas" (2018b, p. 176). Dominada a Baikal, Maria estará pronta a vencer outros embates.

O leitor de Maria dos Canos Serrados acompanha o cotidiano de uma jovem cansada de uma sociedade na qual todos querem tirar vantagem: o Velhinho negligencia Maria, mas usa sua casa para fazer programas; a doutora promete recompensas, mesmo sabendo que a falência da empresa é iminente; o líder sindical usa Maria na reestruturação da firma, mas só permite que ela volte a trabalhar se entrar como acionista; Nandos exige que Maria mantenha relações sexuais com ele, para que ela obtenha a Baikal; a vidente, consultora do futuro, faz apenas previsões positivas e/ou irrelevantes; o senhorio da casa, vendo os aluguéis cada vez mais atrasados, propõe que Maria os pague por meio de favores sexuais... É contra esse mundo que Maria e sua Baikal se voltam; é para essa realidade que os canos serrados apontam.

Maria procura justiça. A partir do encontro com a Baikal, sente-se capaz de investir contra a empresa, a fim de executar o plano do Velhinho: roubar os cartões telefônicos. Maria não está sozinha, visto haver uma legião de vítimas da crise; diante dessa realidade, a jovem coloca-se como justiceira. Os empregados não são responsáveis pela má gestão financeira e merecem a sua parte: "Ao fim de oito meses, onze dias e sete horas, conseguimos receber [roubando os cartões telefônicos] os salários em atraso. Os nossos e de todos os outros pobres. É tão difícil ser pago neste país que não nos admirava que este novo método começasse a ser legal” (2018b, p. 206).

O desfecho do romance - a opção por viver "dedicadas a cem por cento ao gardanho" (2018b, p. 213) - é entregue ao leitor, de maneira velada, já nas primeiras páginas: “O olho da rua fixa-nos. Sabe que o nosso rabo será dele muito em breve. E como o único sector que está a expandir é o do gardanho, sentimo-nos cada vez mais próximas do roubo à mão armada. É a evolução natural" (2018b, p. 10). Palavras inconscientemente proféticas: a perda do emprego, a descoberta da traição, as dívidas e o desejo de obter justiça a todo custo levam Maria a buscar no roubo uma solução para os seus problemas. A narrativa se recobre de tons fatalistas, uma vez que os eventos narrados realmente acarretam a entrada de Maria no mundo do crime. Demonstra-se, assim, que por maior que seja a ilusão de liberdade, o destino de Maria já estava traçado de antemão.

A escalada de violência, na qual o absurdo irrompe, inicia-se no Bar e Salão de Fogo Nandos. Maria vai ao clube de tiros com Luísa e Tina, a fim de obter a Baikal e perpetrar o roubo da empresa; porém é surpreendida pela resistência de Nandos e Geleia e por uma investida inesperada do Velho e Jesus no salão. A cena é cinematográfica: Maria, Jesus, o Velho, Geleia e Nandos for- 
mam um círculo e confrontam-se num tiroteio sangrento, do qual Jesus e o Velho saem feridos. Maria e suas amigas conseguem obter armamento e partem rumo à empresa telefônica, levando consigo o Velho, baleado e praticamente sem sentidos. Jesus, gravemente ferido, é abandonado no chão do clube de tiros.

A segunda etapa da ofensiva justiceira de Maria é a invasão da empresa, seguindo "uma linha de acção improvisada, mais criativa, mais destemida e muito mais cabra. A minha cara" (2018b, p. 205). Nessa cena, cuja violência é temperada com humor, Maria faz a Baikal cantar "com suas duas goelas" e prende no banheiro o vigilante, o novo patrão, a chefe da contabilidade e o chefe do armazém - "achámos que se fechássemos todos na mesma casa de banho [...] pode ser que ainda se divertissem" (2018b, p. 209). Durante o assalto, enquanto mantém trancados os reféns, Maria tem uma epifania: "percebemos como aquele momento era lindo e perfeito. [...] como finalmente sabíamos o que queríamos ser quando fôssemos grandes" (2018b, p. 210). Nesse instante, Maria é seduzida completamente pelo gardanho e compreende que a Baikal estará com ela pelo resto dos seus dias (2018b, p. 21). Um novo prazer se revela: "Orgasmar enquanto se molesta a lei é a nossa nova fantasia" (2018b, p. 210).

Entretanto, como Maria afirma, "O amadorismo é fatal" (2018b, p. 210). A inexperiência - ou o destino? - faz com que um detalhe passe despercebido: os reféns portavam celulares, e logo a polícia interrompe a ação. Com o carro partindo em alta velocidade com o bagageiro aberto, o Velhinho é lançado para fora do veículo - sendo capturado pelos policiais - e os cartões telefônicos roubados se extraviam. A estreia de Maria no mundo do crime não foi promissora em termos financeiros, mas não importa: o essencial foi a libertação dos jugos e dependências.

Após o roubo e a fuga, Maria entende que sofrera uma dupla traição por parte do Velho ("Nunca pensámos que pudesses espetar duas facas de cozinha nas costas na mesma vida", 2018b, p. 213): além de levar clientes para casa, ele foi sozinho ao Nandos, ou seja, havia decidido roubar os cartões telefônicos sozinho, deixando Maria de fora da operação. Quando Jesus pede que ela deponha no tribunal em favor do Velho, preso erroneamente pelo roubo à telefônica, é visível a mudança de atitude:

\footnotetext{
O teu mano pede-nos para que [...] expliquemos ao senhor juiz que a culpa não é sempre dos pretos. [...] prometemos que vamos pensar no teu caso. [...] Começamos a achar que não estás prestes a ser condenado por um crime que não cometeste, mas por todos os crimes de negligência que praticaste contra nós (2018b, p. 214-215).
}

Maria dos Canos Serrados - e não mais Maria - já não cede aos apelos do parceiro; é chegado o ajuste de contas, e o Velhinho será punido por suas negligências. No desfecho do romance, dia do julgamento, Maria se liberta totalmente da dependência afetiva e assume sua nova identidade:

\section{VELHINHO DA NOSSA VIDA,}

Pensámos muito no teu caso, que vai hoje a tribunal, e chegámos à conclusão de que o nosso amor por ti é lindo mas não é à prova de bala. Queremos que te fodas, do fundo do coração.

Maria dos Canos Serrados (2018b, p. 218). 
Segundo Ricœur, "um fecho não conclusivo convém a uma obra que levanta propositadamente um problema que o autor considera insolúvel" e "realça de maneira reflexiva o caráter interminável da temática da obra inteira" (2012, p. 37). Nesse sentido, a trajetória de Maria dos Canos Serrados segue; o romance é apenas o início, a narrativa de formação de uma mulher que decide se tornar responsável pelo seu destino - "somos empresárias por conta própria" (ADOLFO, 2018b, p. 207). Paradoxalmente, nesse universo pulp/noir adolfiano, o advento da Maria senhora de si significa a decadência moral, confirmando o pessimismo inicial do romance: "É a evolução natural" (2018b, p. 10).

\section{Considerações finais}

Ricardo Adolfo é um escritor reconhecido pelo caráter socialmente realista de sua produção literária. No entanto, o realismo social de Adolfo não é engajado; não é denúncia de realidades, nem retrato das mazelas, a fim de propor soluções. A lente de Adolfo - já não fotográfica, mas cinematográfica - capta o real valendo-se de um filtro próprio, construindo uma estética pulp que mostra o mundo da criminalidade, do sexo, dos roubos e das mais variadas misérias humanas de forma caricata, exagerada e, por vezes, jocosa.

Maria dos Canos Serrados - tal como a Baikal que varre todo o ambiente com seus tiros atira para todos os lados e atinge múltiplos aspectos da sociedade. Por meio dos espaços narrativos - a casa, a empresa, o clube de tiros -, desvelam-se as mais diversas realidades, como a negligência, a frustração, a injustiça. Num mundo como esse, não há redenção, e o roubo é o caminho ao alcance.

Por não ser um relato jornalístico, o texto de Adolfo explora recursos estilísticos a fim de reconstruir o real no romance. A mimese da oralidade, com diálogos que subvertem o código escrito para se aproximar da fala e o detalhamento despudorado nas descrições garantem o efeito de real, ao passo que a denominação das personagens e as inverossimilhanças indicam ao leitor que o romance traz uma realidade outra, construída literariamente.

A obra de Ricardo Adolfo, portanto, abre novos caminhos, propondo ao leitor novas temáticas - para além das questões identitárias que tanto fecundaram os romances das décadas anteriores - e consolidando a nova ficção portuguesa, calcada no realismo e na narratividade.

\section{REFERÊNCIAS}

ADOLFO, Ricardo. Entrevista: Ricardo Adolfo. [Entrevista concedida a] Rafael Voigt. A voz da literatura, 04 set. 2018a. Disponível em: <https://www.vozdaliteratura.com/post/entrevista-ricardo-adolfo >. Acesso em: 21 fev. 2021.

ADOLFO, Ricardo. Maria dos Canos Serrados. Porto Alegre: Dublinense, 2018b.

AGOSTINHO. A doutrina cristã: manual de exegese e formação cristã. 3. ed. Tradução por Nair de Assis Oliveira. São Paulo: Paulus, 2002. 
AGUIAR E SILVA, Vítor Manuel de. Teoria da literatura. 3. ed. Coimbra: Almedina, 1979.

AUERBACH, Erich. Mimesis: a representação da realidade na literatura ocidental. 6.ed. Vários tradutores. São Paulo: Perspectiva, 2013.

BARTHES, Roland. O efeito de real. In: O rumor da língua. Tradução por Mario Laranjeira. São Paulo: Cultrix, 2004.

BÍBLIA. Português. Bíblia de Jerusalém. São Paulo: Paulus, 2002.

BOSI, Alfredo. O conto brasileiro contemporâneo. São Paulo: Cultrix, 1978.

CANDIDO, Antonio. A nova narrativa. In: A educação pela noite. 5. ed. Rio de Janeiro: Ouro sobre Azul, 2006. p. 241-260.

CASSIRER, Ernst. Linguagem e mito: uma contribuição ao problema dos nomes dos deuses. Tradução por Jaime Guinsburg e Miriam Schnaidermann. São Paulo: Perspectiva, 1972.

NIETZSCHE, Friedrich. Genealogia da moral. Tradução por Paulo César de Souza. São Paulo: Companhia das Letras, 2009.

PERRONE-MOISÉS, Leyla. Mutações da literatura no século XXI. São Paulo: Companhia das Letras, 2017.

REAL, Miguel. O romance português contemporâneo 1950-2010. Alfragide, Portugal: Caminho, 2012. E-book Kindle.

RICCEUR, Paul. Tempo e narrativa: a configuração do tempo na narrativa. Tradução por Márcia Valéria Martinez de Aguiar. São Paulo: WMF Martins Fontes, 2012.

TODOROV, Tzvetan. Simbolismo e interpretação. Tradução por Maria de Santa Cruz. Lisboa: Edições 70, 1980.

TOMACHEVSKI, Boris. Temática. In: TOLEDO, Dionísio de Oliveira (Org.). Teoria da literatura: formalistas russos. Tradução por Ana Mariza Ribeiro et alii. Porto Alegre: Globo, 1971. p. 169-204.

VAREJÃO, José. Crises na economia portuguesa: filha da crise financeira mundial, 2008-2009. Disponível em: $<$ https://www.ffms.pt/crises-na-economia-portuguesa/5046/filha=-da-crise-financeira-internacional\#: :textEntre\%20desequil\%C3\%ADbrios\%20e\%20est\%C3\%ADmulos\%20p\%C3\%BAblicos,econ\%C3\%B3mico\%20 deteriorou\%2Dse\%20com\%20rapidez>. Acesso em: 06 mar. 2021. 